\title{
二酸化マンガンによるメタノールガスの常温酸化分解に関する研究
}

林 大貴，長岡優輝，関根嘉香*

\author{
東海大学大学院理学研究科 =259-1292 神奈川県平塚市北金目4-1-1
}

\section{Oxidative decomposition of methanol gas by manganese dioxide at room temperature}

\author{
Hiroki HAYASHI, Yuki NAGAOKA and Yoshika SEKINE
}

Graduate School of Science, Tokai University, 4-1-1, Kitakaname, Hiratsuka, Kanagawa, 259-1292 Japan

\begin{abstract}
要 旨
メタノールはこれまで生活環境中の空気污染物質として，あまり注目されてこなかったが，自動車用燃料 や燃料電池の水素源として新たな用途が広がりつつあり，生活環境中にメ夕ノールガスが拡散する可能性が 指摘されている。二酸化マンガンは室温でホルムアルデヒドと反応し二酸化炭素を生成することから, 空気 清浄材料の成分として実用に供されている。この二酸化マンガンが常温でメタノールガスをホルムアルデヒ ドにまで酸化できれば，ホルムアルデヒドの酸化分解と同様に常温常圧下で二酸化炭素にまで無機化できる 可能性がある。そこで本研究では，物性の異なる4種類の二酸化マンガン粒子とメ夕ノールガスの反応性を 密閉式試験で調べた。その結果, 室温において試験容器内の気中メ夕ノール濃度は著しく減衰し，その減衰 速度は二酸化マンガン粒子の比表面積に依存的であった。同時に気中二酸化炭素濃度の有意な増加が観測さ れ，二酸化炭素への転化率は結晶構造に関係した。また反応容器中に中間体として極微量のホルムアルデヒ ドおよびギ酸種の生成を認めた。このことから，二酸化マンガンがメタノールガスに対しても常温酸化分解 活性を有することが明らかとなった。
\end{abstract}

\begin{abstract}
Methanol has become recognized as a potential air pollutant in our living environment because many new uses of methanol are being proposed including automotive fuel and hydrogen source for fuel cell. Manganese dioxide $\left(\mathrm{MnO}_{2}\right)$ is practically used for a major ingredient of air cleaning materials, because it reacts with harmful formaldehyde to give stoichiometrical carbon dioxide even at room temperature. When methanol can be oxidized to formaldehyde by $\mathrm{MnO}_{2}$, methanol can be also converted to carbon dioxide at room temperature. Then, this study aimed to investigate the heterogeneous reaction between gaseous methanol and $\mathrm{MnO}_{2}$ powder in a closed bag under ambient temperature. The results showed methanol concentration in air successfully decreased with time depending on the specific surface area of the $\mathrm{MnO}_{2}$ samples, and significant conversion to carbon dioxide was found with a formation of trace amount of formaldehyde in air and formate species on the surface of $\mathrm{MnO}_{2}$ as intermediates. This means $\mathrm{MnO}_{2}$ also shows high activity in the deep oxidation of methanol to carbon dioxide even at room temperature.
\end{abstract}

Key words: メタノール (Methanol)，二酸化マンガン (Manganese dioxide)，空気清浄 (Air purification), 中間体(Intermediate)，酸化分解(Oxidative decomposition)

\section{1. 緒言}

メタノール (メチルアルコール, $\left.\mathrm{CH}_{3} \mathrm{OH}\right)$ は有機 合成の原料や一般溶剂として幅広く利用され，工業 的に重要な化学物質の一つである。しかしながら， メ夕ノールガスの吸入曝露による健康影響は古くか ら知られており ${ }^{1)}$, 日本産業衛生学会では作業環境 における許容濃度を200 ppmと定めている。メタノー
ルは体内に取り込まれた後, アルコール脱水素酵素 によりホルムアルデヒド $(\mathrm{HCHO})$ に酸化され, さら にアルデヒド脱水素酵素によりギ酸 $(\mathrm{HCOOH})$ に分 解されて尿中に排泄されるため，作業環境におけ るメタノール曝露指標として尿中ギ酸濃度の測定が 有効であると報告されている3”。これまでメ夕ノー ルは生活環境中の空気污染物質としては，あまり注

*Corresponding author（責任著者） Email: sekine@keyaki.cc.u-tokai.ac.jp，Tel: 0463-58-1211(内)3761

受付：2017年3月21日 (Received: 21 March 2017)

受理：2017年4月10日（Accepted: 10 April 2017） 
目されてこなかった。しかしながら近年, メ夕ノー ルを燃料とする自動車が北米を中心に普及しはじめ, また燃料電池の水素源としてメタノールが利用され るなど新たな用途が広がりつつあり, 生活環境中に メ夕ノールガスが拡散する可能性が指摘されてい $3^{1,4)}$ 。

筆者らは先に金属酸化物粒子のガス状空気污染物 質に対する化学反応性に関する一連の研究の中で, 二酸化マンガン $\left(\mathrm{MnO}_{2}\right)$ がホルムアルデヒドを室温 で水 $\left(\mathrm{H}_{2} \mathrm{O}\right)$ 上二酸化炭素 $\left(\mathrm{CO}_{2}\right)$ に分解する現象を初 めて見出した5)。この現象を利用し, 二酸化マンガ ンを有効成分とするパッシブ型分解除去ボード 6.7 や 八ニカム・フィルターおよび空気清浄装置を開発 し，実環境での性能評価息吕を経て，一般住宅にお けるホルムアルデヒドに起因する室内空気污染の予 防・改善技術を提供した。現在, 試料物性の異なる 種々の二酸化マンガンおよびその複合酸化物が新た に合成され, 試料物性(結晶型, 形態, 比表面積, 純度など)や環境条件(温度，湿度など)がホルムア ルデヒドの低温酸化分解に及ぼす影響について数多 くの研究が報告されている ${ }^{11-14)}$

一方, 空気清浄を目的としたメタノールの酸化分 解に関して，学術的基礎が十分に示された文献は 少ない。 Litcheva ${ }^{15)}$ は573〜773 Kにおける $\mathrm{MnO}_{2}-$ $\mathrm{MoO}_{3}$ 系複合酸化物によるメ夕ノールガスの酸化反 応について検討し， $\mathrm{MnO}_{2}$ の組成割合が高くなるほ ど二酸化炭素への転化率が高くなり，二酸化マンガ ンがメタノール酸化の活性中心であると報告してい る。そこで筆者らは, 二酸化マンガンがメタノール ガスを常温ホルムアルデヒドに酸化することができ れば, ホルムアルデヒドの酸化分解と同様に, 常温 常圧下で二酸化炭素まで無機化できるのではないか と考え, 本研究を着想した。本研究の目的は, 二酸
化マンガン粒子とメタノールガスの反応性を調べる ことであり，二酸化マンガンがメタノールガスに対 しても常温酸化分解活性を有することを見出したの で報告する。

\section{2. 方法}

\section{1 二酸化マンガン試料}

二酸化マンガンにはいくつかの多形が存在し, 結 晶構造として $\alpha, \beta, \gamma, \delta, \varepsilon$ および $\lambda$ 型が知ら れ, $\alpha, \beta, \gamma$ 型はトンネル構造， $\delta$ 型は層構造， $\lambda$ 型は 3 次元スピネル構造をとる ${ }^{16)} 。 \varepsilon$ 型は $\gamma$ 型と 類似した構造であるが, ミクロ双晶形成により構造 欠陥を多く有する ${ }^{17)}$ 。本研究では, 先に長岡ら ${ }^{14)}$ が ホルムアルデヒドの常温酸化分解に関する研究で用 いた二酸化マンガン粒子のうち, 和光純薬工業社製 の試薬二酸化マンガン (Reagent Grade $\mathrm{MnO}_{2}$, 以下 RMD と略記する) 1 種類 ( $\varepsilon 48$ ), 日本重化学工業社 製の活性化二酸化マンガン (Activated $\mathrm{MnO}_{2}$, 以下 AMD と略記する) 3 種類 ( $\varepsilon 245, \alpha 276, \quad \gamma$ 163)の合 計 4 試料を用いた。Table 1に各試料の物性を示す。 AMDは比表面積の大きい球状多孔質の二酸化マン ガンであり，製法を変えて結晶構造の異なる試料を 得た。AMDの比表面積は163〜276 $\mathrm{m}^{2} / \mathrm{g}$ (BET法)で

Table 1 Material properties of $\mathrm{MnO}_{2}$ samples used in this study

\begin{tabular}{ccccc}
\hline \hline Type & $\begin{array}{c}\text { Crystal } \\
\text { structure }\end{array}$ & $\begin{array}{c}\text { Sprcific surface } \\
\text { area }\left(\mathrm{m}^{2} / \mathrm{g}\right)\end{array}$ & Purity (\%) & Abbrev. \\
\hline RMD & $\varepsilon$ & 48 & 85.0 & $\varepsilon 48$ \\
AMD & $\varepsilon$ & 245 & 81.3 & $\varepsilon 245$ \\
AMD & $\alpha$ & 276 & 80.9 & $\alpha 276$ \\
AMD & $\gamma$ & 163 & 87.4 & $\gamma 163$ \\
\hline
\end{tabular}

RMD: Reagent grade $\mathrm{MnO}_{2}$

AMD: Activated $\mathrm{MnO}_{2}$
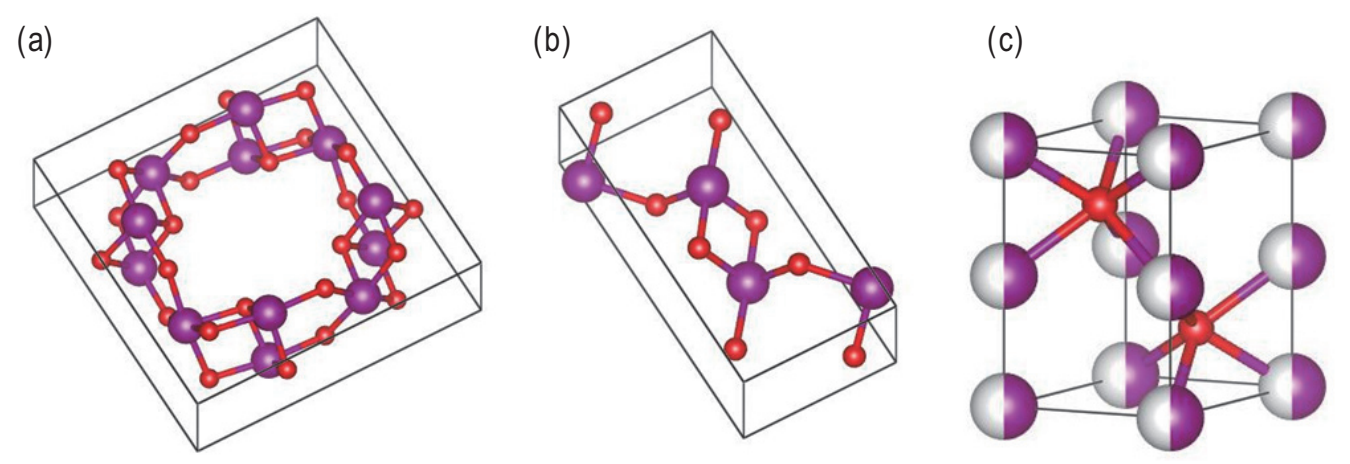

Fig.1 Crystal forms of manganese dioxide used in this study

(a) $\alpha$-type, (b) $\gamma$-type, (c) $\varepsilon$-type 
あり，RMDに比べて比表面積が大であった。AMD 中の $\mathrm{MnO}_{2}$ としての純度は80.9 87.4\%であり, 比表 面積が大きくなるにつれて純度が低下する傾向にあっ た。Fig.1に $\alpha, \gamma$ および $\varepsilon$ 型 $\mathrm{MnO}_{2}$ の結晶構造を示 す。

\section{2 メタノールガス分解試験}

メタノールガスと二酸化マンガン粒子の反応性を 調べるため, 密閉式バッチ試験を行った。試料 $5.0 \mathrm{~g}$ をャーレ(内径 $67 \mathrm{~mm} \times$ 高さ $15 \mathrm{~mm}$ ) に展開 し，これを10 Lのフッ素樹脂製サンプリングバッ グに入れ, 脱気した後, メタノールガスを導入して 密閉した。メタノールガスは，インピンジャーに希 釈したメタノール水溶液を $10 \mathrm{~mL}$ 入れ, 清浄空気を 導入してバブリングすることで得た。濃度レベルは, 許容濃度の2倍值 $(400 \mathrm{ppm})$ とした。メタノールは 和光純薬工業社製の試薬特級を用いた。サンプリン グバッグ中の気中メタノールガスおよび二酸化炭素 濃度を密閉してから1，2，3，4，5，6，7および24 時間後に気体検知管 (ガステック社製, No.111L, $111 \mathrm{LL}$ および2LC)により測定し，(1)式から時間 $t$ に 打けるメタノールの二酸化炭素への転化率 $Q(\%)$ を 算出した。

$$
Q=\frac{\left[\mathrm{CO}_{2}\right]_{t}-\left[\mathrm{CO}_{2}\right]_{0}}{\left[\mathrm{CH}_{3} \mathrm{OH}\right]_{0}-\left[\mathrm{CH}_{3} \mathrm{OH}\right]_{t}} \times 100
$$

試験開始前の空試験で, サンプリングバッグ内の メタノールガス濃度が減衰しないことを確認した。 試験時の実験室内の温度は298 Kであった。

\section{3 反応生成物の追跡試験}

反応容器としてフッ素樹脂製サンプリングバッグ $(10 \mathrm{~L})$ を 7 枚用意し, 内6枚に $\varepsilon 48$ 粒子 $5.0 \mathrm{~g}$ を展開 したシャーレ(内径 $67 \mathrm{~mm} \times$ 高さ $15 \mathrm{~mm}$ )を設置し た。残りの1枚にはシャーレのみ設置した。次にす ベてのバッグにメタノール液をマイクロピペットで 直接注入して密閉し，これに純空気 $10 \mathrm{~L}$ 導入し てメタノールを気化させた(即時に気化した)。シャー レのみを設置したバッグを反応初期 $(t=0)$ とみなし, 以後， $\varepsilon 48$ 粒子を設置したバッグについて $1 ， 2 ， 3$, 4, 7および24時間後にメタノール, 二酸化炭素, ホ ルムアルデヒドおよびギ酸の気中濃度, さらに二酸 化マンガン粒子上のギ酸種 $\left(\mathrm{HCOO}^{-}\right)$を定量した。各
成分の測定方法は以下の通りである。

気中メタノールおよび二酸化炭素濃度 : 2.2 と同 様, 気体検知管を用いて測定した。

気中ホルムアルデヒド濃度 : ホルムアルデヒドの 測定には2,4-ジニトロフェニルヒドラジン(DNPH)含 浸カートリッジ捕集 - 高速液体クロマトグラフ法を 用いた。サンプリングバッグにDNPH含浸カートリッ ジ(GL Science社製, Mini AERO DNPH)およびミニ ポンプ(柴田科学社製MP- $\left.\sum 300 \mathrm{~N}\right)$ を取り付け，バッ グ内の空気を 2.0 L捕集した。捕集後, DNPH誘導 体をアセトニトリルで溶出し, $10 \mathrm{~mL}$ に定容して試 料溶液とした。ホルムアルデヒド濃度の定量には高 速液体クロマトグラフ法を用いた。装置の構成は以 下の通りである。送液ポンプ：日立社製 L-2130, UV 検出器: 日立社製 L-2400, 分離カラム : GL Science社製 Inertsil-ODS3, $5 \mu \mathrm{m}, 4.6 \mathrm{~mm} \times 150 \mathrm{~mm}$, 溶離液: アセトニトリル/水 $=60 / 40$, 流量 : 0.5 $\mathrm{mL} / \mathrm{min}$, インジェクション量 : $20 \mu \mathrm{L}$, 吸光度測定 波長：360 nm。定量下限值 (LOQ) はブランク值の 標準偏差の 10 倍と定義し, 本捕集条件では $0.85 \mu \mathrm{g} /$ $\mathrm{m}^{3}$ であった。

気中ギ酸濃度：ミゼットインピンジャーに捕集液 として $1 \mathrm{mM}$ 水酸化カリウム水溶液 $15 \mathrm{~mL}$ 入れ, ミニポンプ(柴田科学社製 MP- $\left.\sum 300 \mathrm{~N}\right)$ に接続して バッグ内の空気を 2.0 L吸引した。捕集後, 捕集溶 液中のギ酸イオンをイオンクロマトグラフ装置によ り定量した。装置の構成は以下の通りである。送液 ポンプ: Dionex社製 ICS-90, 検出器: 電気伝導検 出器, ガードカラム: Dionex社製 Ion Pack AS-9-HC Guard, $4 \mathrm{~mm} \times 50 \mathrm{~mm}$, 分離カラム : Dionex社製 Ion Pack AS-9-HC Analytical, $4 \mathrm{~mm} \times 250 \mathrm{~mm}$, 再生液: $15 \mathrm{mM}$ 硫酸溶液, 溶離液 : $5.0 \mathrm{mM}$ 炭酸ナトリウ

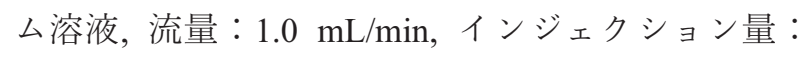
$25 \mu \mathrm{L}$ 。定量下限值 (LOQ) はブランク值の標準偏差 の10倍と定義し, 本捕集条件では $12 \mu \mathrm{g} / \mathrm{m}^{3}$ であった。 固相表面上のギ酸種: 使用した $\varepsilon 48$ 粒子をサンプ リングバッグから取り出し, $0.50 \mathrm{~g} 5.0 \mathrm{~mL}$ のイオ ン交換水で振とう抽出した。次いで10分間遠心分離 を行い, 得られた上澄み液の内 $2 \mathrm{~mL}$ を過し, 万 液中のギ酸イオン濃度をイオンクロマトグラフ装置 により定量した。 

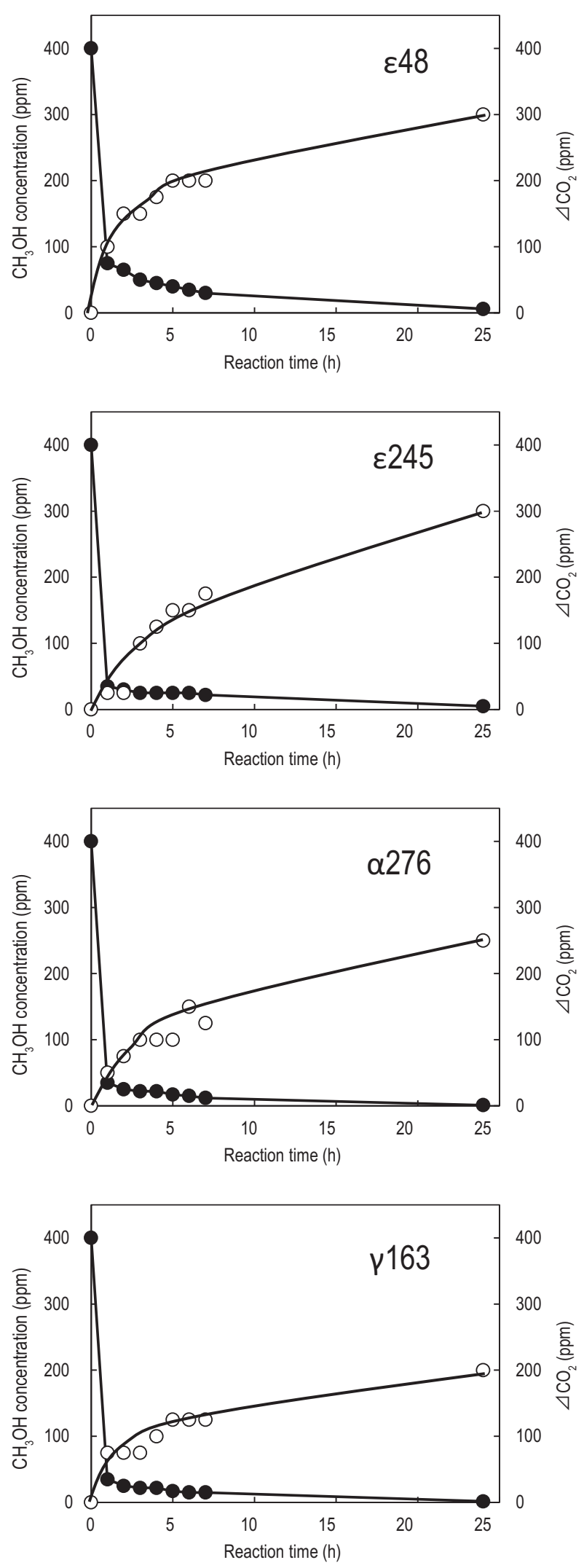

Fig.2 Time courses of concentrations of $\mathrm{CH}_{3} \mathrm{OH}(-)$ and produced $\mathrm{CO}_{2}(\mathrm{O})$ in a closed sampling bag at $298 \mathrm{~K}$ employing four kinds of $\mathrm{MnO}_{2}$ samples $(n=2$, $\mathrm{MnO}_{2}: 5.0 \mathrm{~g}$, volume: $10 \mathrm{~L}$ )

\section{3. 結果}

\section{1 メタノールガスの常温酸化分解}

密閉式バッチ試験に打ける気中メタノールガス濃 度および二酸化炭素の増加量 $\triangle C \mathrm{CO}_{2}\left(=\left[\mathrm{CO}_{2}\right]_{t}-\right.$ $\left.\left[\mathrm{CO}_{2}\right]_{0}\right)$ の経時変化をFig.2に示す。各プロットは，2 回繰り返し実験の平均值である。いずれの試料にお いてもメタノールガス濃度は著しく減衰し, 減衰速 度は $\alpha 276 \fallingdotseq \varepsilon 245>\gamma 163>\varepsilon 48$ の順となり, 比表 面積が大きくなるほど減衰速度が高くなる傾向にあっ た。これは比表面積が大きいほど，メタノールガス の吸着速度が高くなるためと考えられる。一方, サ ンプリングバッグ内に打ける $\triangle \mathrm{CO}_{2}$ の変化に着目す ると, いずれの試料に扔いても二酸化炭素濃度の顕 著な増加が見られた。このことから, 二酸化マンガ ンはメタノールガスを常温である298Kで二酸化炭 素にまで分解したことがわかる。

Table 2 に各試料の反応開始 24 時間後における $\mathrm{CO}_{2}$ 転化率を示す。 $\mathrm{CO}_{2}$ 転化率は， $\varepsilon 48: 76 \%$, $\varepsilon 245: 76 \% ， \alpha 276: 63 \%$ ，また $\gamma 163 ： 50 \%$ となっ た。長岡らは既報年に抢いてホルムアルデヒドから 二酸化炭素への転化率に対して，二酸化マンガンの 結晶構造の影響は見いだせなかったと報告している が，メタノールの酸化分解に関しては $\varepsilon$ 型二酸化マ ンガンの試料で高い転化率となった。また，比表面 積あたりの転化率は， $\varepsilon 48>\varepsilon 245 \fallingdotseq \gamma 163>\alpha 276$ となり, 同じ結晶構造の場合は純度の高い試料 ( $\varepsilon 48)$ で高い $\mathrm{CO}_{2}$ 転化率を示した。比較として, 同 じ試験方法により $500 \mathrm{ppm}$ のルムアルデヒドガス を出発物質とした時の比表面積あたりの $\mathrm{CO}_{2}$ 転化 率 ${ }^{14}$ をTable 2に併記する。メ夕ノールガスを出発 物質とする時の $\mathrm{CO}_{2}$ 転化率は, ホルムアルデヒドガ スを出発物質とする時の 10 分の 1 程度であり, ホル

Table 2 Conversion rates from $\mathrm{CH}_{3} \mathrm{OH}$ to $\mathrm{CO}_{2}$ normalized by specific surface area of $\mathrm{MnO}_{2}$ powders in a closed sampling bag ( $t=24 \mathrm{~h}$, temp.: $298 \mathrm{~K})$

\begin{tabular}{ccccc}
\hline \hline & \multicolumn{3}{c}{ Conversion rate at 24h } \\
\cline { 2 - 3 } Sample & \multicolumn{2}{c}{ from $\mathrm{CH}_{3} \mathrm{OH}$} & & from $\mathrm{HCHO}^{*}$ \\
\cline { 2 - 3 }$\varepsilon 48$ & 76 & $\left(\% / \mathrm{m}^{2}\right)$ & & $\left(\% / \mathrm{m}^{2}\right)$ \\
$\varepsilon 245$ & 76 & 0.32 & & 3.5 \\
$\alpha 276$ & 63 & 0.062 & & 0.70 \\
$\gamma 163$ & 50 & 0.046 & & 0.60 \\
\hline
\end{tabular}

* Cited from Nagaoka et al. $(2015)^{14)}$ 
ムアルデヒドを原料とする場合に比べて二酸化炭素 の生成速度が緩やかであることがわかる。これは反 応物から生成物に至るまでの反応ステップ数の相違 によるためと考えられる。

\section{2 反応生成物の追跡試験}

メ夕ノールは分解の過程で, 中間体 (ホルムアル デヒド，ギ酸種)を経て二酸化炭素に変化すると考 えられる。そこで, メ夕ノールガスと二酸化マンガ ン粒子の反応機構を考察するため， $\varepsilon 48$ を用いて反 応物 (メ夕ノールガス), 中間生成物および最終生成 物 (二酸化炭素) を追跡調査した。Table 3に各反応 時間におけるサンプリングバッグ内の各成分の物質 量 $(\mu \mathrm{mol})$ を示す。表中の值は, 3 回繰り返し実験の 平均值である。

気中メ夕ノール量の減少につれて, 一時的に極微 量のホルムアルデヒドガスが検出され, 次いで二酸 化マンガン粒子上にギ酸種が生成し，ギ酸種の減少 につれて気中の二酸化炭素量が増加した。尚, 気相 中にギ酸ガスは検出されなかった。

これらの結果から次の反応機構が推定される。尚, 以下の $(1) \sim(6)$ 式中の $(\mathrm{g})$ はガス状， $(\sigma)$ は固体表面 上の活性点に吸着した状態をそれぞれ表す。二酸化 マンガンによるメタノールの酸化は不均一反応に基 づいており, メ夕ノール分子は結晶格子中の酸素 $(\mathrm{O}(\sigma))$ によホルムアルデヒドに酸化される。

$$
\mathrm{CH}_{3} \mathrm{OH}+\mathrm{O}(\sigma) \rightarrow \mathrm{HCHO}(\sigma)+\mathrm{H}_{2} \mathrm{O} \quad \cdots(1)
$$

ホルムアルデヒドは揮発性が高いため, 気相中に ごくわずかに放散される。

$$
\operatorname{HCHO}(\sigma) \rightleftarrows \mathrm{HCHO}(\mathrm{g})
$$

しかしながらホルムアルデヒドは, 二酸化マンガ ンの結晶格子中の酸素と速やかに反応し, 中間体で あるギ酸種を経て二酸化炭素および水に分解され $3^{8)}$ 。中間体の $\operatorname{HCOO}(\sigma)$ は, 水溶媒で抽出されると ギ酸イオンとして検出されるが, ギ酸ガスとして気 相に放出されることはない。一方, 生成した二酸化 炭素は固体表面から脱離し, 気相に拡散すると考え られる。

$$
\begin{aligned}
& \operatorname{HCHO}(\sigma)+\mathrm{O}(\sigma) \rightarrow \operatorname{HCHOO}(\sigma) \\
& \operatorname{HCHOO}(\sigma) \rightarrow \operatorname{HCOO}(\sigma)+\mathrm{H}(\sigma)
\end{aligned}
$$

Litchevaは ${ }^{15)}$, $598 \mathrm{~K}$ におけ $\mathrm{MnO}_{2}-\mathrm{MoO}_{3}$ 系複合 酸化物によるメタノールガス酸化時の気相生成物を 検討し, $\mathrm{MnO}_{2}$ 単独では二酸化炭素のみが生成し, $\mathrm{MoO}_{3}$ が増加するにつれてホルムアルデヒドの生成 量が増加すると報告している。メタノールガスの無 機化には，ホルムアルデヒドの酸化過程を経ねばな らず，常温に拈いても二酸化マンガンを用いること により, 二酸化炭素を最終生成物として得ることが できることが明らかとなった。

Table 3 Mass table of the reactant, possible intermediates and product during the course of reaction of methanol gas with $\varepsilon 48$ in the closed sampling bags (temp.: $293 \mathrm{~K}, \varepsilon 48: 5.0 \mathrm{~g}$, volume:10L, Unit: $\mu \mathrm{mol})$

\begin{tabular}{ccccccc}
\hline \hline Time $(\mathrm{h})$ & $\mathrm{CH}_{3} \mathrm{OH}(\mathrm{g})$ & $\mathrm{HCHO}(\mathrm{g})$ & $\mathrm{HCOO}^{-}$ & $\mathrm{HCOOH}(\mathrm{g})$ & $\mathrm{CO}_{2}(\mathrm{~g})$ & Total \\
\hline 0 & 208 & $<\mathrm{LOD}$ & $\mathrm{ND}$ & $<\mathrm{LOD}$ & $<\mathrm{LOD}$ & 208 \\
1 & 78 & 0.34 & 1.3 & $<\mathrm{LOD}$ & 32 & 111 \\
2 & 62 & 0.43 & 1.0 & $<\mathrm{LOD}$ & 76 & 140 \\
3 & 35 & 0.32 & 1.5 & $<\mathrm{LOD}$ & 114 & 150 \\
4 & 28 & 0.25 & 0.84 & $<\mathrm{LOD}$ & 130 & 159 \\
7 & 10 & 0.12 & 0.84 & $<\mathrm{LOD}$ & 173 & 184 \\
24 & 7 & $<\mathrm{LOD}$ & 0.18 & $<\mathrm{LOD}$ & 200 & 207 \\
\hline
\end{tabular}

$<$ LOD: below LOD, ND: Not detected 


\section{4. 結言}

メタノールは自動車用燃料や燃料電池の水素源と して用途が広がりつつあり, 今後生活環境中にメ夕 ノールガスが拡散し, 室内空気污染を引き起こす可 能性がある。本研究において, 二酸化マンガン粒子 とメタノールガスの反応性を密閉式試験で調べた結 果, 二酸化マンガンがメタノールガスに対しても常 温酸化分解活性を有することが明らかとなり，室内 空気污染対策材料としての利用可能性が示唆された。

\section{謝辞}

本研究を遂行するにあたり, 活性化二酸化マンガ ン試料を提供して頂いた日本重化学工業株式会社・ 白子響氏，木村絵夢氏に記して深く感謝申し上げま す。

\section{引用文献}

1) Vyskocil, A., Viau, C.: Proposal for reference concentrations (RfC) for inhalation exposure to methanol, Environ. Toxicol. Pharmacol., 9, 9-18 (2000).

2) Liesivuori, J., Savalainen, H.: Urinary formic acid as an indicator of occupational exposure to formic acid and methanol, Am. Ind. Assoc. J., 48(1), 32-34 (1987).

3) Ogata, M., Iwamoto, T., Kawai, T.: Enzymatic assay of urinary formic acid as an index of methanol exposure, Ind. Health, 27, 125-129 (1989).

4) Ernstgård, L., Shibata, E., Johanson, G.: Uptake and Disposition of Inhaled Methanol Vapor in Humans, Toxicol. Sci., 88 (1), 30-38 (2005).

5) Sekine, Y.: Oxidative decomposition of formaldehyde by metal oxides at room temperature, Atmos. Environ., 36, 5543-5547 (2002).

6) Sekine, Y., Nishimura, A.: Removal of formaldehyde from indoor air by passive type air-cleaning board, Atmos. Environ., 35, 2001-2007 (2001).

7) 関根嘉香, 西村厚司 : 室内空気中HCHO除去用 パッシブ型分解除去ボードの開発, 臭気の研究, 30(1), 39-47 (1999).
8) 関根嘉香, 藤江真也, 小田達也：HCHO除去用 空気清浄器の性能評価, 資源環境対策誌35(5), 9-14 (1999).

9）小座野貴弘, 関根嘉香, 末永義明, 小峯裕己： 化学物質に起因する室内空気污染の対策技術の 開発一空気清浄機による室内HCHOの除去, 日 本建築学会計画系論文集，536，55-62 (2000).

10) 関根嘉香, 西村厚司, 末永義明, 小峯裕己：室 内空気中HCHOおよびギ酸濃度の実態調査と低 減化実験，日本建築学会計画系論文集，548， 51-55 (2001).

11) Tang, X., Li, Y., Huang, X., Xu, Y., Zhu, H., Wang, J., Shen, W.: MnOx-CeOx catalysts for complete oxidation of formaldehyde: Effect of preparation method and calcinations temperature, Applied $\mathrm{Ca}$ talysis B: Environment, 62, 265-273 (2006).

12) Tang, X., Chen, J., Huang, X., Xu, Y., Shen, W.: $\mathrm{Pt} / \mathrm{MnOx}-\mathrm{CeOx}$ catalysts for the complete oxidation of formaldehyde at ambient temperature, Applied Catalysis B: Environment, 81, 115-121 (2008).

13) Wang, Z., Pei, J., Zhang, J.: Catalytic oxidation of indoor formaldehyde at room temperature- Effect of operation conditions, Buid. Environ., 65, 49-57 (2013).

14）長岡優輝, 関根嘉香, 木村絵夢：二酸化マンガ ンの結晶構造がホルムアルデヒドの常温酸化分 解に及ぼす影響, 室内環境, 18(1), 27-32 (2015).

15) Litcheva, P. A.: Catalytic purification of gases polluted with methanol, J. Environ. Protect. Ecology, 3(1), 187-190 (2002).

16) Devaraj, S., Munichandraiah, N.: Effect of Crystallographic Structure of $\mathrm{MnO}_{2}$ on Its Electrochemical Capacitance Properties, J. Phys. Chem. C, 112, 4406-4417 (2008).

17) Zhou, L., Zhang, J., He, J., Hub, Y., Tian, H.: Control over the morphology and structure of manganese oxide by tuning reaction conditions and catalytic performance for formaldehyde oxidation, Materials Research Bulletin, 46, 1714-1722 (2011). 